\title{
Hydrocarbon generation from Carboniferous-Permian coaly source rocks in the Huanghua depression under different geological processes
}

\author{
Jin-Jun $\mathrm{Xu}^{1,2} \cdot$ Qiang Jin ${ }^{1}$
}

Received: 13 March 2020 / Published online: 4 November 2020

(c) The Author(s) 2020

\begin{abstract}
Natural gas and condensate derived from Carboniferous-Permian (C-P) coaly source rocks discovered in the Dagang Oilfield in the Bohai Bay Basin (east China) have important implications for the potential exploration of C-P coaly source rocks. This study analyzed the secondary, tertiary, and dynamic characteristics of hydrocarbon generation in order to predict the hydrocarbon potentials of different exploration areas in the Dagang Oilfield. The results indicated that C-P oil and gas were generated from coaly source rocks by secondary or tertiary hydrocarbon generation and characterized by notably different hydrocarbon products and generation dynamics. Secondary hydrocarbon generation was completed when the maturity reached vitrinite reflectance $\left(R_{\mathrm{o}}\right)$ of $0.7 \%-0.9 \%$ before uplift prior to the Eocene. Tertiary hydrocarbon generation from the source rocks was limited in deep buried sags in the Oligocene, where the products consisted of light oil and gas. The activation energies for secondary and tertiary hydrocarbon generation were $260-280 \mathrm{~kJ} / \mathrm{mol}$ and $300-330 \mathrm{~kJ} / \mathrm{mol}$, respectively, indicating that each instance of hydrocarbon generation required higher temperature or deeper burial than the previous instance. Locations with secondary or tertiary hydrocarbon generation from C-P coaly source rocks were interpreted as potential oil and gas exploration regions.
\end{abstract}

Keywords Hydrocarbon generation · Thermal simulation · Coaly source rocks · Carboniferous-Permian · Huanghua depression

\section{Introduction}

Huanghua Depression is one of the most petroliferous depressions in the Bohai Bay Basin of east China, and the main source rocks for accumulations are Paleogene lacustrine source rocks that generate large amounts of oil and gas (Hao et al. 2007; Li et al. 2015; Liang et al. 2018). Coaly source rocks were deposited under the basin during the

\section{Edited by Jie Hao}

Jin-Jun Xu

xujj2015@upc.edu.cn

1 Key Laboratory of Deep Oil and Gas, China University of Petroleum (East China), Qingdao 266580, Shandong, China

2 Pilot National Laboratory for Marine Science and Technology, China University of Petroleum (East China), Aoshanwei Wenhai Road 1, Qingdao 266237, Shandong, China
C-P period, leading to the discovery of gas and condensate in drilling wells within the C-P sandstone reservoirs and buried-hill reservoirs in deep parts of the basin (Liu et al. 2017; Zhao et al. 2018). For example, gas and condensate produced from well Gbg1 in the Zhanhua sag and well Su20 on the Suqiao-Wenan slope of the Jizhong sag both originate from C-P coaly source rocks (Dai and Xia 1990; Liu et al. 2017; Gong et al. 2018). In 2017-2018, large quantities of crude oil $\left(30.2 \mathrm{~m}^{3} / \mathrm{d}\right)$ and gas $\left(8 \times 10^{4} \mathrm{~m}^{3} / \mathrm{d}\right)$ were produced at depths of 4956.8-4984.9 $\mathrm{m}$ in sandstones from well $\mathrm{Yg} 1$, and at depths of 3836-3841 m in Ordovician buried-hill carbonate reservoirs from well Qg8 in Dagang Oilfield of the China National Petroleum Corporation (CNPC), which revealed great potential for $\mathrm{C}-\mathrm{P}$ oil and gas exploration (Zhao et al. 2018).

During the Paleozoic, there was a huge platform over north China (Liu 1990; He et al. 1991), onto which coalbearing sediments were deposited during the C-P period (Lv et al. 2011; Chang et al. 2016; He et al. 2016; Fig. 1). Previous studies have indicated three instances of tectonic 


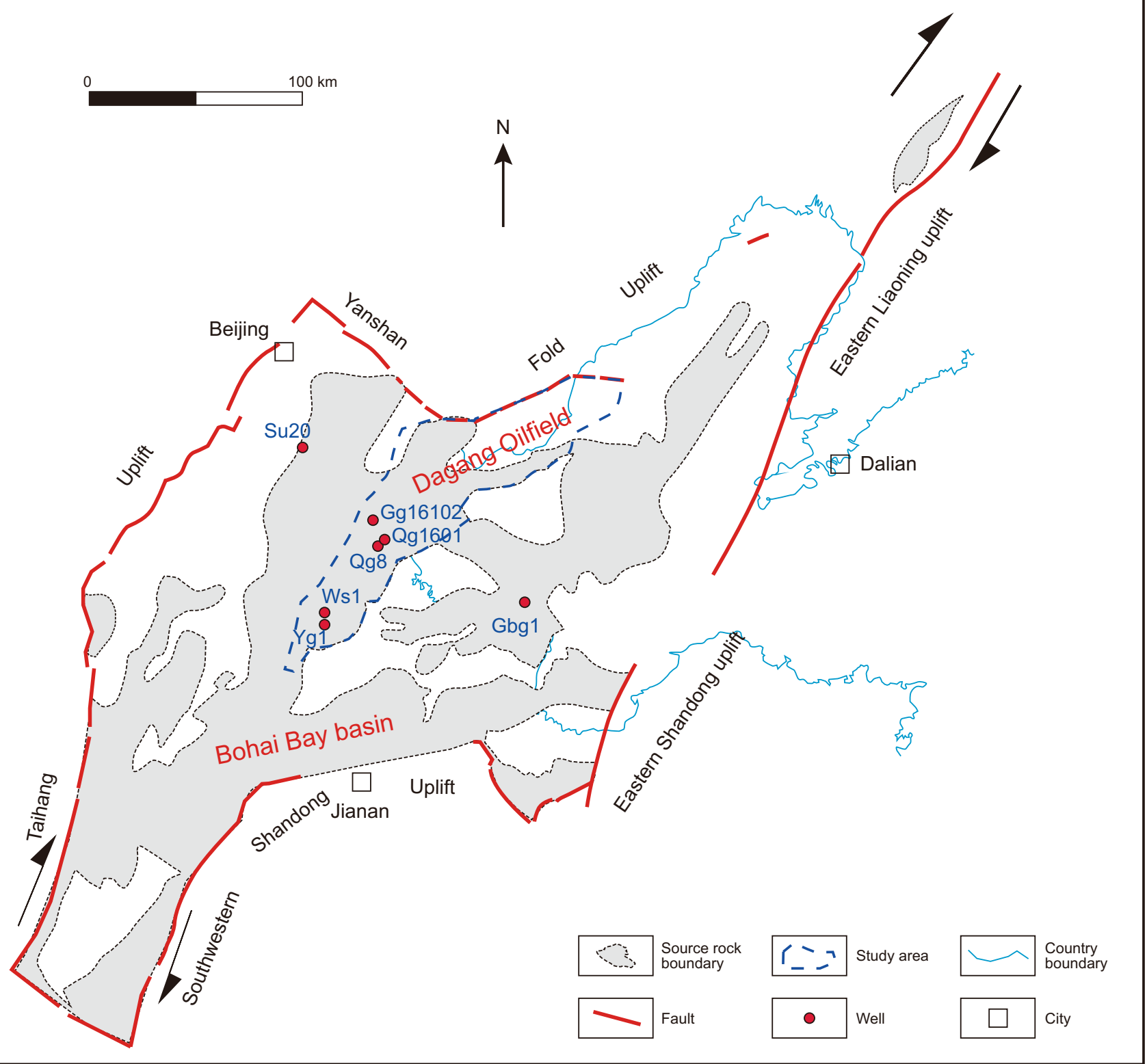

Fig. 1 Distribution of residual coal source rocks in eastern China

subsidence and two uplift events since the Triassic (T) (Allen et al. 1998; Chang et al. 2018). The coaly source rocks were then buried and reached a mature stage during the mid-T, generating small quantities of hydrocarbons; this was the first instance of hydrocarbon generation (primary hydrocarbon generation) (Zhang et al. 2014; Chang et al. 2018). The end of primary hydrocarbon generation was caused by uplift from the late T (Jin et al. 2009). During the Jurassic ( $\mathrm{J})$ to Cretaceous $(\mathrm{K})$, a rift basin formed in east China (Allen et al. 1998; Zhou et al. 2012). Some C-P strata were buried to great depths, generating hydrocarbons for the second time (early-secondary hydrocarbon generation) (Qi and Yang 2010; Li et al. 2012; Zhao et al. 2015). During the late $K$ to Paleocene (E), secondary hydrocarbon generation was terminated at the end of rift development (Zhou et al. 2012). Coaly source rocks that were not buried to sufficient depths in the J-K period did not generate oil or gas during this period; however, sufficient burial for oil and gas generation did occur during the tertiary rifting stage (late-secondary hydrocarbon generation from E). Since the Eocene, a new rift basin developed on residual J-K strata, with some of the coaly source rocks buried deep beneath the sag areas of the rift generating oil 
and gas for a third time (tertiary hydrocarbon generation) (Zheng et al. 2007; Belaid et al. 2010; Chang et al. 2018).

As the C-P strata are buried deep below the Bohai Bay Basin, few drilling wells have penetrated these layers; therefore, the distribution of C-P strata beneath the basin has become a key area of geological research (Huang et al. 2010; Chang et al. 2018; Zhao et al. 2018). However, the locations of secondary or tertiary hydrocarbon generation of coaly source rocks in the basin, as well as the quantity of oil and gas generation, should be determined prior to further exploration. The distribution of residual C-P strata in the Huanghua Depression, including that of coaly source rocks, has previously been determined (Tian et al. 1996; He et al. 2016; Zhao et al. 2018). Therefore, the purpose of this study is to investigate the quantity of oil and gas generated from coaly source rocks under the Huanghua Depression of Bohai Bay Basin by analyzing the secondary, tertiary, and dynamic characteristics of hydrocarbon generation with the aim of predicting the hydrocarbon potentials of different exploration areas.

\section{Geological setting}

Dagang Oilfield is located at $37^{\circ} 30^{\prime}-39^{\circ} 50^{\prime} \mathrm{N}$ and $116^{\circ} 10^{\prime}-119^{\circ} 30^{\prime} \mathrm{E}$ in the Huanghua Depression of the Bohai Bay Basin (Fig. 1), which is a typical Mesozoic and Cenozoic extensional basin in the center of the eastern part of the North China Craton Block (Su et al. 2014; Li et al. 2015). Dagang Oilfield is oriented in a north-northeast direction covering an area of $1.7 \times 10^{4} \mathrm{~km}^{2}$. Many studies have analyzed the distribution of residual C-P coaly source rocks in eastern China, which are found throughout almost the entire Dagang Oilfield except for Qikou sag, where they have been eroded (Huang et al. 2010; Chang et al. 2018; Zhao et al. 2018; Fig. 1). The residual C-P source rocks are also found in Dagang Oilfield. Thus, widespread C-P coaly source rocks in the study area provide abundant materials for hydrocarbon generation.

Three types of coaly source rocks found in the study area, including coal, carbonaceous mudstone, and dark shale, were deposited in a paralic environment during the C-P period. The C-P succession contains the Benxi Formation $\left(\mathrm{C}_{2} \mathrm{~b}\right)$, Taiyuan Formation $\left(\mathrm{C}_{2} \mathrm{t}\right)$, Shanxi Formation $\left(\mathrm{P}_{1} \mathrm{~s}\right)$, and Shihezi Formation $\left(\mathrm{P}_{1} \mathrm{sh}\right)$, which is comprised of thick (418.0-1768.5 m), unconformable, siliciclastic-dominated, shallow-marine and paralic deposits overlying Middle Ordovician carbonates (Fig. 2; Kim et al. 2001). C-P coaly source rocks in the Shanxi Formation (67.0-195.5 m) were deposited in a continental sedimentary environment, whereas source rocks of the Taiyuan Formation $(87.5-229.0 \mathrm{~m}$ ) were formed in a paralic environment ( $\mathrm{Li}$ et al. 2001; Lv and Chen 2014; Zhao et al. 2017; Fig. 2). Both the depositional environment and amount of erosion affect the thickness of coal, carbonaceous mudstone, and dark mudstone layers.

\section{Samples and methods}

\subsection{Samples and data}

A total of 23 coal samples were collected from well Gg16102 and Longkou mine, three of which were selected as thermal experimental samples (Fig. 1; Table 1). The maceral composition, $R_{\mathrm{o}}$, total organic carbon content (TOC), and Rock-eval pyrolysis were determined for Dagang oil field source rock samples and Longkou mine samples collected from wells Gg16102, Kg4, Qg1601, Xu14, Ws1, and Ts1.

\subsection{Methods}

\subsubsection{Thermal history recovery}

Many previous investigations speculated that the geothermal gradient reached $3.5^{\circ} \mathrm{C} / 100 \mathrm{~m}$ from late $\mathrm{P}$ to early $\mathrm{T}$ and then increased to approximately $5.0{ }^{\circ} \mathrm{C} / 100 \mathrm{~m}$ in the Mesozoic due to strong magmatic activity before decreasing again to $3.5^{\circ} \mathrm{C} / 100 \mathrm{~m}$ during the Cenozoic (Li et al. 2007a, b; Zhang et al. 2014). Based on the burial history recovery of coaly source rocks and the paleogeothermal gradient, the hydrocarbon generation history of coaly source rocks in typical wells was recovered using the Easy\% $R_{\mathrm{o}}$ method (Schenk et al. 2017). The initial maturities of primary, secondary, and tertiary hydrocarbon generation processes were also identified according to the thermal evolution history curve.

\subsubsection{Thermal simulation experiments and kinetic parameter calculation}

The thermal simulator can separately resist high temperatures and high pressures up to $800{ }^{\circ} \mathrm{C}$ and $120 \mathrm{MPa}$, respectively (Fig. 3). Samples are closed in the autoclave and accompanied by nitrogen or distilled water (to represent $25 \%$ of the sample mass) and heated by a heater strip with a set heating rate. Based on the results of previous experiments, the relationship between $R_{\mathrm{o}}$ and temperature was fitted (Fig. 4). $R_{\mathrm{o}}$ values serve as a "bridge" connecting the actual degree of thermal evolution and the thermal simulation degree. With a heating rate of $60^{\circ} \mathrm{C} / \mathrm{h}$, all coal samples were heated at $50{ }^{\circ} \mathrm{C}$ intervals to simulate the actual geologic conditions of source rocks within different areas during their thermal history.

Among the coaly source rocks, the coal exhibited greater hydrocarbon generation potential with a mean of greater than $11 \mathrm{mg} / \mathrm{g}$ of $\mathrm{S}_{1}+\mathrm{S}_{2}$ dominating the generation of coal-related 


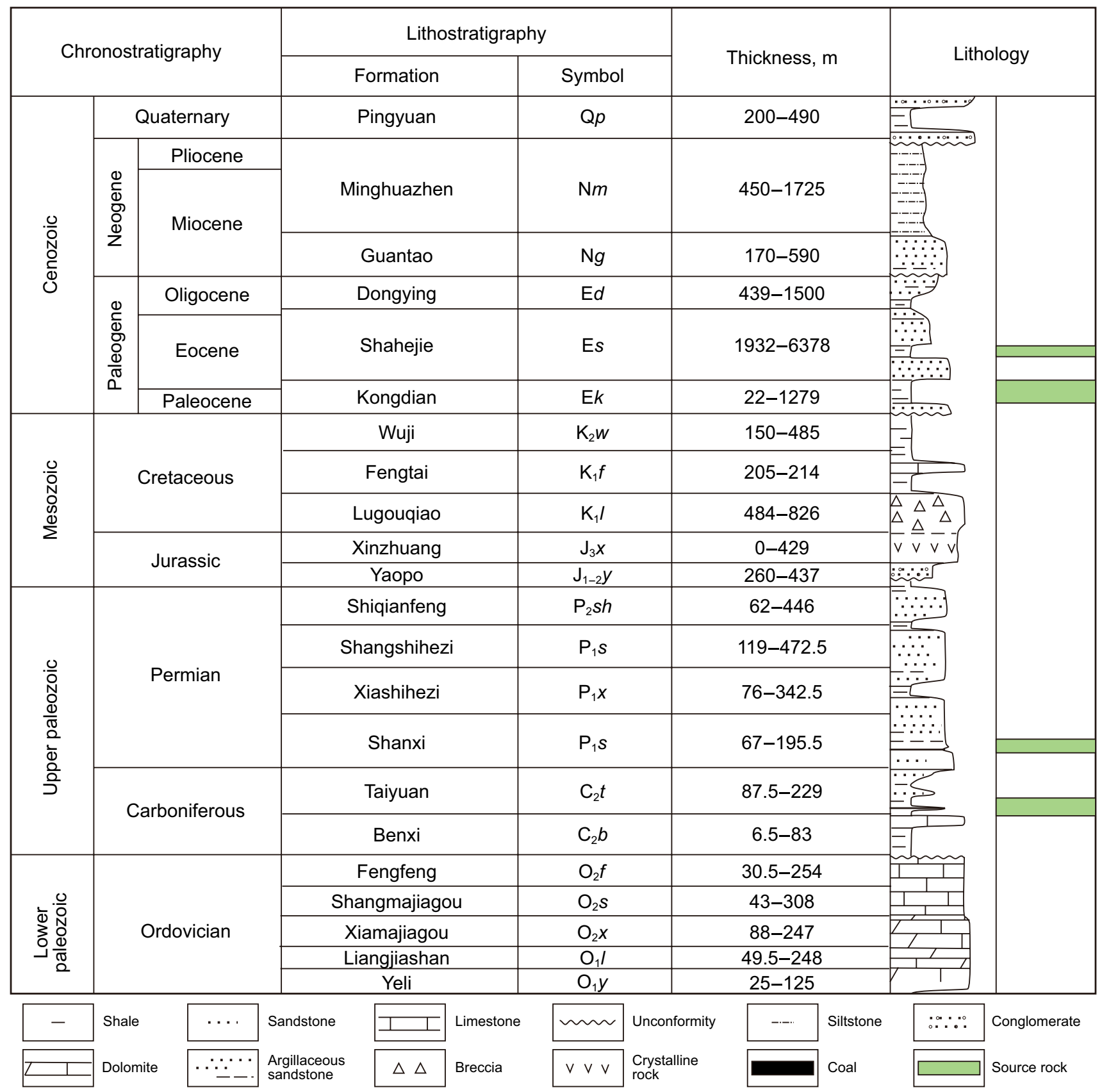

Fig. 2 Stratigraphic profile and distribution of main source rocks in Dagang Oilfield (modified from Zhao et al. 2018)

Table 1 Organic geochemical characteristics and maceral composition of different coals

\begin{tabular}{|c|c|c|c|c|c|c|c|c|}
\hline \multirow[t]{2}{*}{ Samples } & \multirow[t]{2}{*}{$R_{\mathrm{o}}, \%$} & \multirow[t]{2}{*}{$T_{\max },{ }^{\circ} \mathrm{C}$} & \multirow[t]{2}{*}{$\mathrm{S}_{2}, \mathrm{mg} / \mathrm{g}$} & \multirow[t]{2}{*}{ TOC, $\%$} & \multirow{2}{*}{$\begin{array}{l}\text { Hydrogen index, } \\
\mathrm{mg} / \mathrm{g} \text { TOC }\end{array}$} & \multicolumn{3}{|c|}{ Maceral content, $\%$} \\
\hline & & & & & & Vitrinite & Exinite & Inertinite \\
\hline Torbanite Longkou & 0.41 & 407 & 250.90 & 57.54 & 435.9 & 60.6 & 39.4 & 0.0 \\
\hline Humic coal Longkou & 0.41 & 407 & 92.16 & 61.33 & 150.3 & 93.8 & 6.0 & 0.2 \\
\hline C-P Coal Well Gg16102 & 0.67 & 432 & 124.63 & 65.56 & 190.1 & 87.1 & 11.5 & 1.2 \\
\hline
\end{tabular}



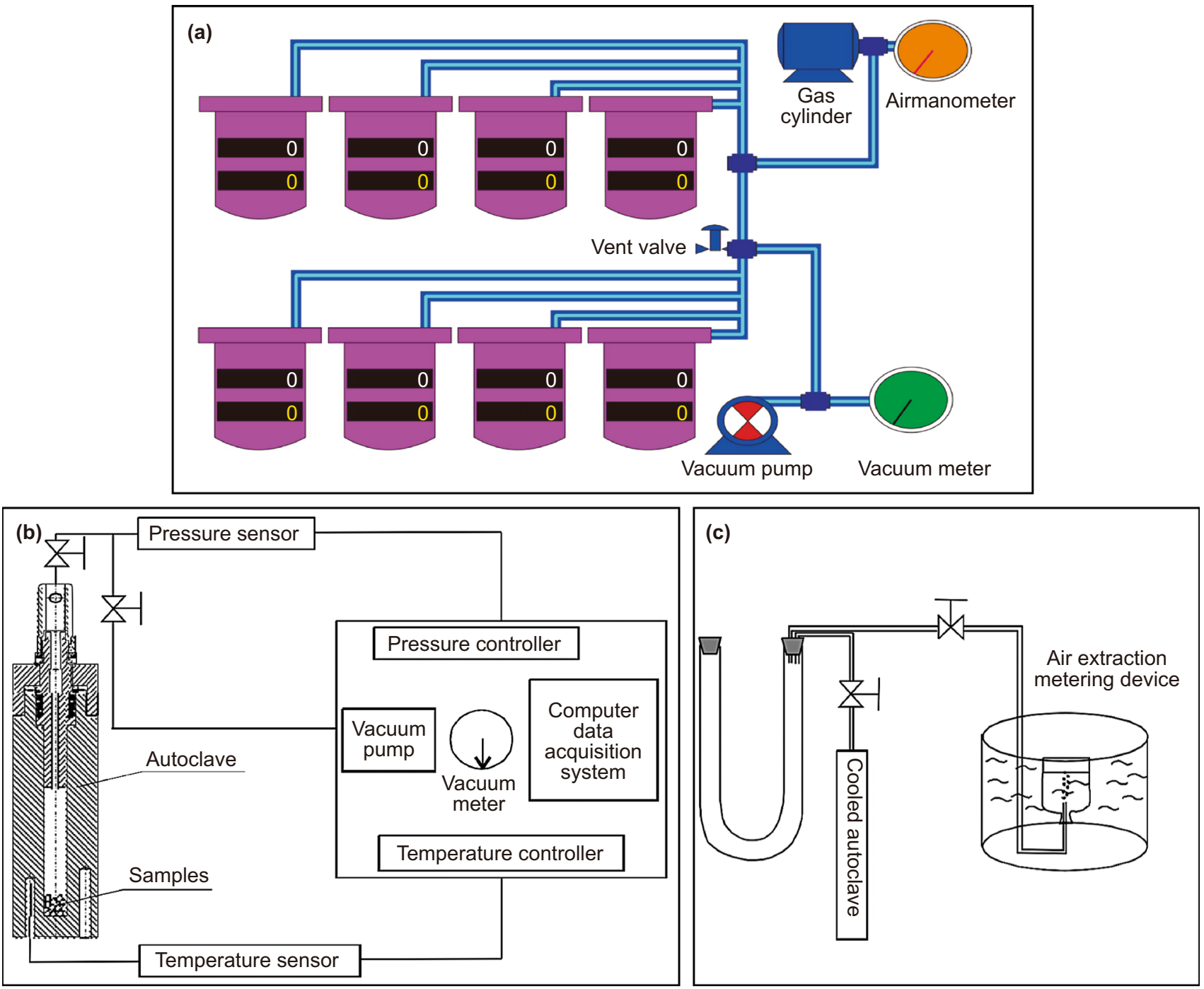

Fig. 3 Schematic showing the thermal simulation of hydrocarbon generation. a The thermal simulator consists of eight autoclaves connected to a gas cylinder and vacuum pump; $\mathbf{b}$ each autoclave is monitored by temperature and pressure controllers. The liquid hydrocarbon production in the autoclave was collected at each temperature point after cooling and opening; $\mathbf{c}$ the gas hydrocarbon production was collected using the saturated saltwater displacement method

crude and condensate; therefore, coal was selected as the experimental sample for thermal simulation (Ahmed et al. 2009; Zhao et al. 2018). According to the thermal evolution history, three instances of hydrocarbon generation occurred, with regional subsidence developing during the early $\mathrm{T}$ and all coaly source rocks reaching maturity at approximately $0.65 \% R_{\mathrm{o}}$ (Jin et al. 2009), which is represented by the coaly source rocks in the uplift area or outside of the Bohai Bay Basin (e.g., southwestern Shandong). Therefore, no immature samples of C-P coaly source rocks were available in the present-day sedimentary strata. To prepare an immature sample for the thermal simulation of primary hydrocarbon generation, an experimental sample was prepared from $\mathrm{E}$ coal collected from the Longkou mine of Shandong Province according to the proportion of vitrinite and exinite of C-P coal in the Bohai Bay Basin (Fig. 1). During the thermal simulation of primary hydrocarbon generation, the temperature was increased from 300 to $650^{\circ} \mathrm{C}$ with 5-7 g of sample collected at every temperature point (total of eight points). The coal sample for thermal simulation of secondary hydrocarbon generation was collected from Gg16102 and exhibited lower initial maturity of secondary hydrocarbon generation $\left(0.67 \% R_{\mathrm{o}}\right)$. In the thermal simulation of secondary hydrocarbon generation, the sample was also heated from 350 to $650{ }^{\circ} \mathrm{C}$. The simulation was ended at a temperature of $375{ }^{\circ} \mathrm{C}$, when the sample reached a maturity value of $0.76 \%$ $R_{\mathrm{o}}$. The autoclave was cooled to room temperature and then heated again to perform thermal simulation of secondary hydrocarbon generation with higher initial maturity $(0.76 \%$ $R_{\mathrm{o}}$ ) from 400 to $650{ }^{\circ} \mathrm{C}$. An experimental sample with a 


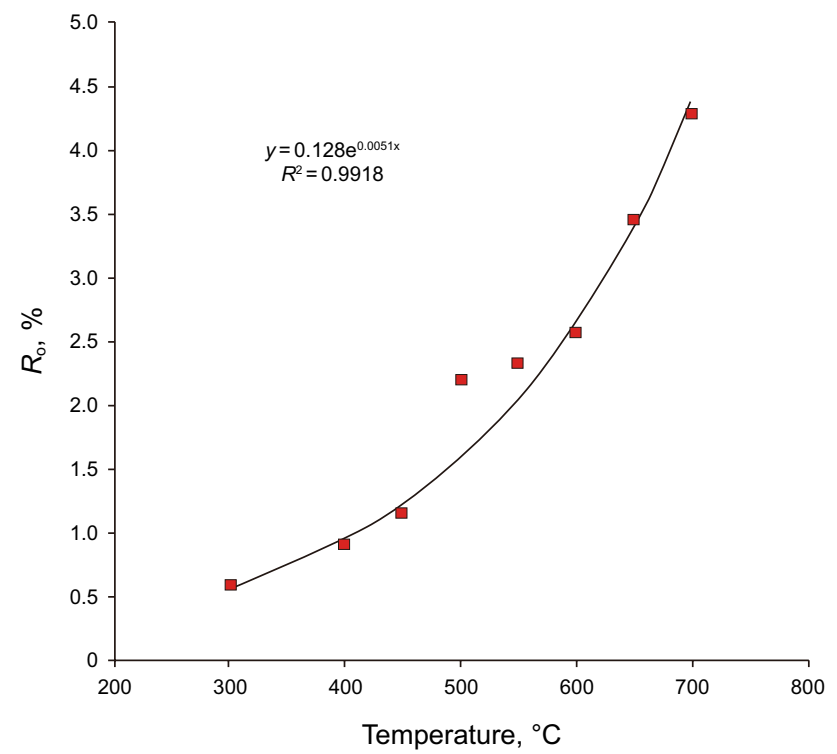

Fig. 4 Relationship between simulation temperature points and maturity

maturity of $0.9 \% R_{\mathrm{o}}$ was prepared at a temperature of $400{ }^{\circ} \mathrm{C}$ from a coal sample of well Gg16102 and then cooled. All hydrocarbon generation processes were heated to $650{ }^{\circ} \mathrm{C}$ with 5-7 $\mathrm{g}$ of sample collected at every temperature point. The materials produced at each $50{ }^{\circ} \mathrm{C}$ interval during the thermal simulation were then collected. The generated liquid hydrocarbon of each temperature point was extracted from the heated residual using dichloromethane. The weight of oil production was weighed after the volatilization of the extraction. Gas hydrocarbons were collected using the method of saturated salt solution displacement (Dai et al. 2013).

The kinetic parameters of coal cracking were calculated according to the method of Wang et al. (2015) based on parallel first-order reaction models, which are kinetic models with multiple frequency factors (MFF models) and a range of activation energies. Hydrocarbon generation is assumed to involve a series of parallel first-order reactions, including the activation energy of reaction $i\left(\mathrm{EG}_{i}\right)$, the pre-exponential factor of reaction $i\left(\mathrm{AG}_{i}\right)$, and the generation potential of the reaction or reaction fraction $i\left(\mathrm{XG}_{i}\right)(i=1,2, \ldots, \mathrm{NKH})$. The formula, derived from the first-order reaction rate equation and the Arrhenius formula, calculates the total mass of hydrocarbon generation of the $N G$ parallel reaction: where $D$ is the heating rate $(\mathrm{K} / \mathrm{min})$; $T$ is the absolute temperature $(\mathrm{K}) ; R$ is the gas constant $(8.31447 \mathrm{~kJ} /(\mathrm{mol} \mathrm{K}))$; and $\mathrm{XG}_{i 0}$ is the value of $\mathrm{XG}_{i}$ at the onset of coal thermal degradation. In this study, the calculated activation energy was the average of all hydrocarbon generation.

\subsubsection{Gas chromatography analysis}

Subsequently, the samples were extracted by a Soxhlet apparatus with dichloromethane for $72 \mathrm{~h}$. The extracts were then fractionated by open silica gel column chromatography using $n$-hexane. The resulting saturated hydrocarbons and all products were analyzed by gas chromatography (GC) with an Agilent 5890 N GC analyzer for quantitative analysis.

\section{Results and discussion}

\subsection{Multi-part thermal history of coaly source rocks}

\subsubsection{Characteristics of the three hydrocarbon generation events}

According to their timing and order, the hydrocarbon generation events were divided into three types: primary hydrocarbon generation, secondary hydrocarbon generation, and tertiary hydrocarbon generation. Occurring in the early $\mathrm{P}$ to middle $\mathrm{T}$, the primary hydrocarbon generation area was characterized by shallow burial, with maturity of less than $0.80 \% R_{\mathrm{o}}$ (Zhang et al. 2014), and classified as the initial oil generation stage (Fig. 5a). Part of the primary hydrocarbon generation area remained buried at a shallow depth, with some locations uplifted and eroded from the late $\mathrm{T}$ to the present. Owing to deep burial during either the Mesozoic or Cenozoic, secondary hydrocarbon generation occurred in the Xuhei area during the late $\mathrm{J}$ to early $\mathrm{K}$ with structural subsidence (Fig. 5d). The coaly source rocks of the Qibei slope and Qikou sag were deeply buried and underwent thermal evolution, generating petroleum for a second time from the Neogene (Fig. 5c, e). The tertiary hydrocarbon generation area developed in the early to middle $\mathrm{T}$, the late $\mathrm{J}$ to early $\mathrm{K}$, and during the E period. As a result of its burial history, tertiary hydrocarbon generation occurred during a wet or dry gas phase (Fig. 5f; Zhao et al. 2018).

$$
\mathrm{XKH}=\sum_{i=1}^{\mathrm{NKH}} \mathrm{XG}_{i}=\sum_{i=1}^{\mathrm{NG}}\left(\mathrm{XG}_{i 0}\left(1-\exp \left(-\int_{T_{0}}^{T}\left(\mathrm{AG}_{i} / D\right) \cdot \exp \left(-\mathrm{EG}_{i} / R \cdot T\right) \mathrm{d} T\right)\right)\right)
$$




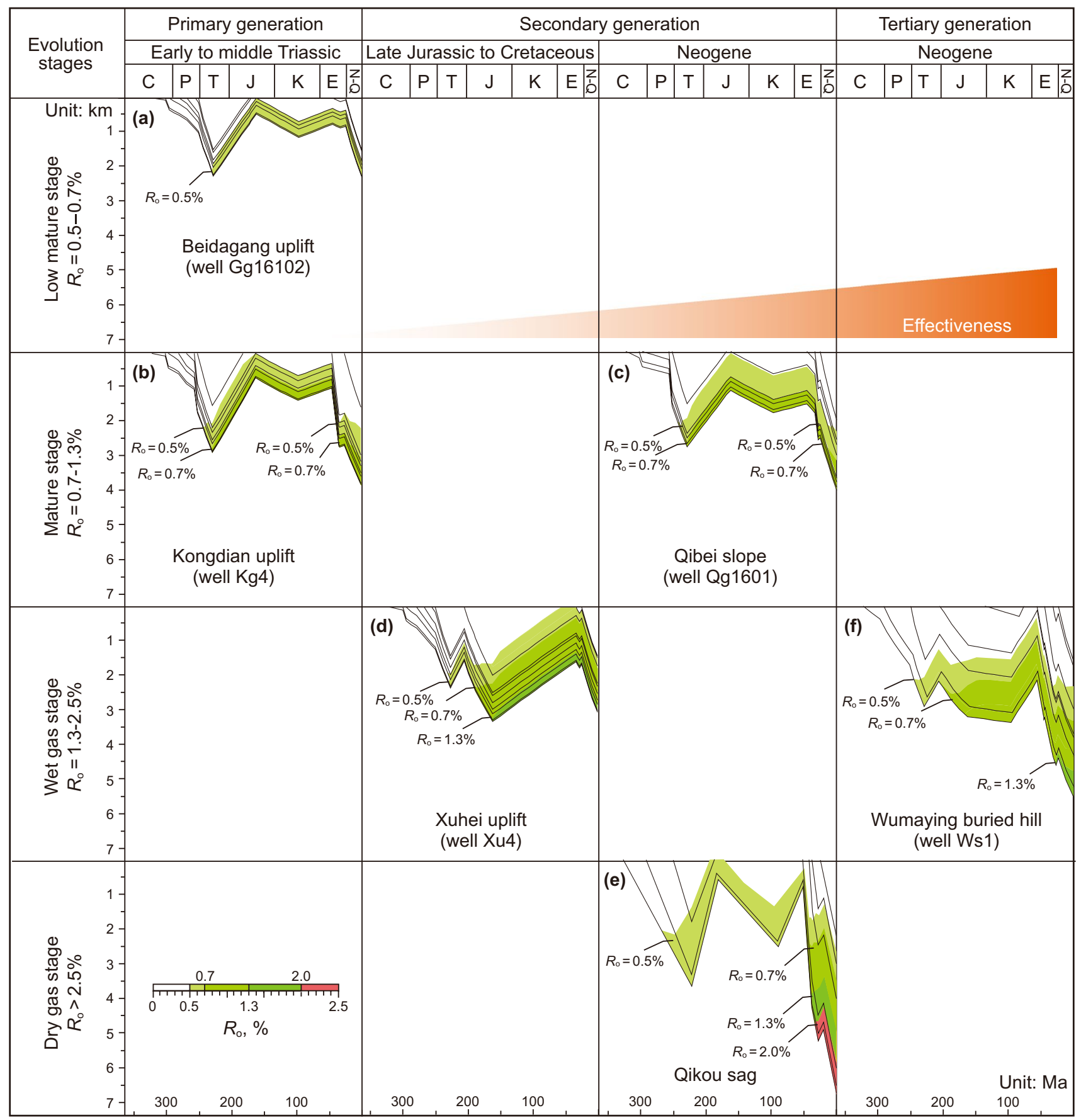

Fig. 5 Stages of hydrocarbon generation within the Huanghua Depression. a and b primary hydrocarbon generation during the early to mid-T with maturity of $0.67 \% R_{\mathrm{o}}$ and $0.76 \% R_{\mathrm{o}}$, respectively; c Neogene late-secondary hydrocarbon generation with low maturity of $1.1 \% R_{\mathrm{o}}$; $\mathbf{d}$ earlysecondary hydrocarbon generation during the late $\mathrm{J}$ to early $\mathrm{K} ; \mathbf{e}$ Neogene late-secondary hydrocarbon generation with maturity above $2.0 \% R_{\mathrm{o}} ; \mathbf{f}$ Neogene tertiary hydrocarbon generation reached a maturity of $1.6 \% R_{\mathrm{o}}$

\subsubsection{Geological conditions of multiple hydrocarbon generation events}

According to our reconstruction of the hydrocarbon generation history, geological models were established for different areas. The models provide accurate experimental reference conditions for setting parameters based on the relationship between maturity and heating temperature (Table 2; Fig. 4). Based on the influences of temperature and depth, the initial and ceasing $R_{\mathrm{o}}$ values of 
Table 2 Geological model of multiple hydrocarbon generation events in Huanghua Depression

\begin{tabular}{|c|c|c|c|c|c|c|c|c|c|}
\hline \multirow[t]{3}{*}{ Types } & \multirow{3}{*}{$\begin{array}{l}\text { Hydrocarbon } \\
\text { generation } \\
\text { event }\end{array}$} & \multirow[t]{3}{*}{ Presentative wells } & \multicolumn{6}{|c|}{ Generation processes evolution $\left(R_{\mathrm{o}} / \%\right)$} & \multirow[t]{3}{*}{ Current burial depth } \\
\hline & & & \multicolumn{2}{|l|}{ C-T } & \multicolumn{2}{|l|}{$\mathrm{J}-\mathrm{K}$} & \multicolumn{2}{|l|}{ E to now } & \\
\hline & & & Initial point & Final point & Initial point & Final point & Initial point & Final point & \\
\hline A & Primary & Gg16102 & 0.5 & 0.67 & - & - & - & - & $<3500$ \\
\hline $\mathrm{B}_{2}^{1}$ & Secondary & Ts 1 & 0.5 & 0.67 & - & - & 0.67 & 1.1 & $3500-5500$ \\
\hline $\mathrm{B}_{2}^{2}$ & & Qg1601 & 0.5 & 0.76 & - & - & 0.76 & 1.1 & $3500-5500$ \\
\hline $\mathrm{C}$ & Tertiary & Ws1 & 0.5 & 0.67 & 0.67 & 0.9 & 0.9 & 1.6 & $>5500$ \\
\hline
\end{tabular}

different hydrocarbon generation events were identified from thermal history diagrams, in which temperature is the dominant factor. The $R_{\mathrm{o}}$ values of primary hydrocarbon generation ended at $0.67 \%$ for wells Gg16102 and Ts 1 and $0.76 \%$ for well $\mathrm{Qg} 1601 . R_{\mathrm{o}}$ values of early-secondary hydrocarbon generation and late-secondary hydrocarbon generation reached $0.9 \%$ and $1.1 \%$, respectively. Tertiary hydrocarbon generation of well Ws1 finally attained a $R_{\mathrm{o}}$ value of $1.6 \%$ (Table 2).
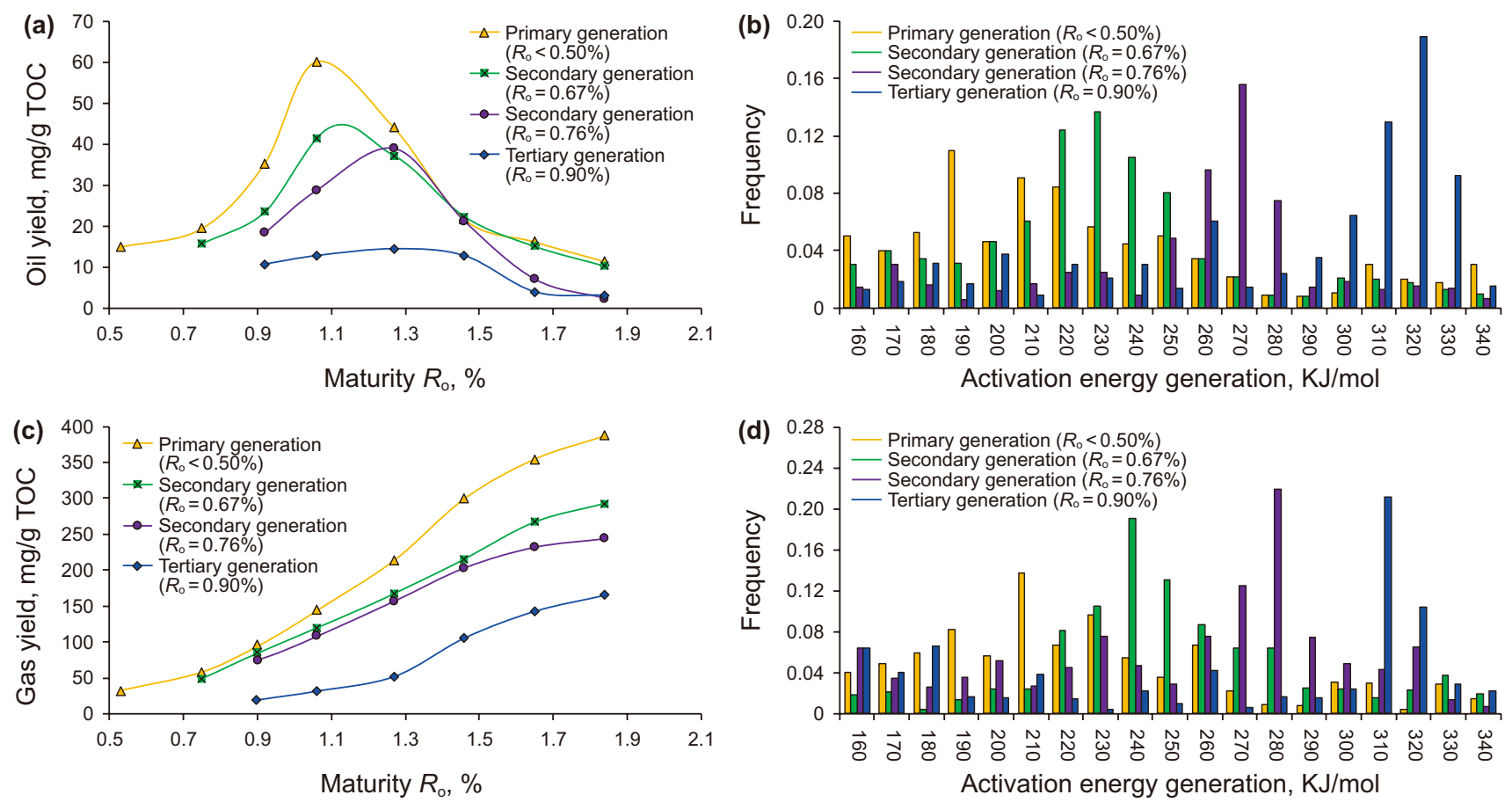

Fig. 6 Hydrocarbon generation yield and activation generation distributions of coal samples during the three hydrocarbon generation events. The primary hydrocarbon generation samples are a matched-immature sample from Longkou mine coal. The early-secondary hydrocarbon generation sample is coal from well $\mathrm{Gg} 16102$. The late-secondary hydrocarbon generation and tertiary hydrocarbon generation samples are coal from well Gg 16102 prepared and heated at $375{ }^{\circ} \mathrm{C}$ and $400{ }^{\circ} \mathrm{C}$, respectively 
at $450{ }^{\circ} \mathrm{C}\left(R_{\mathrm{o}}=1.06 \%\right)$ with a yield of $60.12 \mathrm{mg} / \mathrm{g}$ TOC. Subsequently, the oil yield began to decrease after $650{ }^{\circ} \mathrm{C}$ $\left(R_{\mathrm{o}}=1.84 \%\right)$ (Fig. 6a). Compared to primary hydrocarbon generation, the maximum yield of secondary hydrocarbon generation with the early "oil window" phase $\left(0.67 \% R_{\mathrm{o}}\right)$ appeared at approximately $450{ }^{\circ} \mathrm{C}\left(R_{\mathrm{o}}=1.06 \%\right)$. The highest oil yield of $41.52 \mathrm{mg} / \mathrm{g}$ TOC was substantially lower than that of primary hydrocarbon generation (Fig. 6a). A higher initial maturity of $0.76 \%$ reduced the amount of oil produced by secondary hydrocarbon generation; the maximum yield of $39.01 \mathrm{mg} / \mathrm{g}$ TOC was less than that of primary and earlysecondary hydrocarbon generation events. The lowest quantity of oil compounds was obtained at $650{ }^{\circ} \mathrm{C}\left(R_{\mathrm{o}}=1.84 \%\right)$ with a yield of only $2.38 \mathrm{mg} / \mathrm{g}$ TOC. However, with a higher initial maturity point $\left(R_{\mathrm{o}}\right.$ value of $\left.0.90 \%\right)$, an oil yield of $10.67 \mathrm{mg} / \mathrm{g}$ TOC was obtained. The oil peak of tertiary hydrocarbon generation occurred after $500{ }^{\circ} \mathrm{C}\left(R_{\mathrm{o}}=1.27 \%\right)$ with a lower yield of $14.40 \mathrm{mg} / \mathrm{g}$ TOC. At the end of heating $\left(650{ }^{\circ} \mathrm{C}, R_{\mathrm{O}}=1.84 \%\right)$, the remaining oil potential declined to nearly zero (Fig. 6a), with the curve of tertiary hydrocarbon generation shown as a straight line, representing a low oil yield.

The characteristics of the different generation events suggest that the production quantity and generation curves are controlled by the initial maturity. With increasing maturity, the yield peaks gradually decreased and the curve transformed from a normal to low-amplitude shape (Fig. 6a). Moreover, the decrease in oil potential was controlled by the difference in initial maturity between the two generation events.

\subsubsection{Total decrease in gas generation}

The differences in gas generation among the three hydrocarbon generation events are clearly observed in Fig. 6c, in which the generation curves increase continuously with temperature. With increasing maturity, the total gas production decreased substantially at all temperature points. The maximum gas yield was $387.29 \mathrm{~mL} / \mathrm{g}$ TOC, obtained during primary hydrocarbon generation at $650{ }^{\circ} \mathrm{C}\left(R_{\mathrm{o}}=1.84 \%\right)$. Correspondingly, the minimum yield of $165.23 \mathrm{~mL} / \mathrm{g}$ TOC was obtained at $650{ }^{\circ} \mathrm{C}$ during tertiary hydrocarbon generation. Due to the higher initial maturity $\left(R_{\mathrm{o}}=0.9 \%\right)$ of tertiary hydrocarbon generation, gas production was clearly lower than that during primary and secondary hydrocarbon generation events. Moreover, the gas yield exhibited a greater decrease between early-secondary and late-secondary hydrocarbon generation at higher temperature (Fig. 6c). Again, the initial maturity was the most important factor affecting petroleum production; the higher the initial maturity, the lower the gas production from primary hydrocarbon generation to tertiary hydrocarbon generation events.

\subsubsection{Increase in activation energy generation with time}

The distribution of activation energy reflects the order of chemical compounds generated during hydrocarbon generation events (Dieckmann 2005). Laboratory experiments have determined the kinetics describing the rate of thermal decomposition of kerogen to petroleum (Pepper and Corvi 1995; Dieckmann 2005; He et al. 2018a, b). The activation energy varied considerably among the three hydrocarbon generation events with different initial maturities (Fig. 6b, d). All events exhibited a broad distribution of activation energies; however, with increasing initial maturity, the activation energy distribution shifted toward higher values from primary hydrocarbon generation to tertiary hydrocarbon generation events, accompanied by an increase in the frequency factor $\left(A_{\mathrm{f}}\right)$.

Primary oil generation exhibited a broader distribution, centered around $180-220 \mathrm{~kJ} / \mathrm{mol}$ with a maximum value of $190 \mathrm{~kJ} / \mathrm{mol}$ and an $A_{\mathrm{f}}$ value of $5.87-9.3 \times 10^{14}$. Due to the low thermostability, heteroatomic compounds, small molecule benzenes, and alkyl benzenes preferentially cracked and generated light hydrocarbons during primary hydrocarbon generation (Li et al. 2007a, b; Yu et al. 2012). At an initial maturity of $0.67 \% R_{\mathrm{o}}$, secondary oil generation exhibited an almost symmetrical distribution centered on approximately $230 \mathrm{~kJ} / \mathrm{mol}\left(A_{\mathrm{f}}=8.64 \times 10^{14}\right)$. A higher activation energy distribution reflects the formation of short chains of aliphatic functional groups and oxygen containing groups with higher thermostability, such as isoparaffinic, naphthenic, and normal alkane hydrocarbons ( $\mathrm{Li}$ et al. 2007a, b; Yu et al. 2012). For a similar initial maturity, a small increase in activation energy of late-secondary hydrocarbon generation was observed from 260 to $280 \mathrm{~kJ} /$ $\operatorname{mol}\left(A_{\mathrm{f}}=1.01-6.34 \times 10^{14}\right)$ compared to previous oil generation (Fig. 6b). Compared to the generation event of $0.67 \%$ $R_{\mathrm{o}}$, more normal alkanes and short chains of aromatic and methyl benzol would form, corresponding to a higher activation energy (Walker et al. 2007; Petersen et al. 2009; Chen et al. 2012; He et al. 2018a, b). The activation energy of $300-330 \mathrm{~kJ} / \mathrm{mol}\left(A_{\mathrm{f}}=4.86-5.94 \times 10^{14}\right)$ for tertiary hydrocarbon generation was substantially higher than that for primary and secondary oil generation events. With increasing maturity, a higher activation energy indicates the cracking of long chains of aliphatic hydrocarbons and aromatic hydrocarbons with long side chains. The kerogen may originate from angiosperm and gymnosperm pollens containing cutinite and sporinite that generate hydrocarbons at considerably higher maturities of $0.85 \% R_{\mathrm{o}}$ or higher (Petersen and Nytoft 2006; Petersen et al. 2009; Yu et al. 2012; Chen et al. 2012; He et al. 2018a, b).

The activation energy distributions of the multiple gas generation events are similar to those of the multiple oil generation events. The shift from lower to higher activation 
energy for both oil and gas generation indicates that petroleum generation increased from primary to secondary to tertiary hydrocarbon generation events. The differences in yield among the multiple petroleum generation events agreed closely with the variations of activation energy. The primary hydrocarbon generation event with the lowest activation energy more easily produced petroleum, as shown by the higher hydrocarbon yield and earlier peak. Oil and gas yield notably decreased with increasing activation energy. Thus, the reduction in petroleum yield depended on the different activation energies of different generation events (Fig. 6b).

Even within the same generation event, oil and gas generation was dominated by the activation energy. That is, during primary and secondary hydrocarbon generation events, the main activation energies of gas generation were all approximately $10-20 \mathrm{~kJ} / \mathrm{mol}$ greater than those of oil generation, indicating that oil was more easily produced than gas compounds. Consequently, the oil yield was larger and occurred earlier than the gas yield (Fig. 6a, c). Conversely, due to the high initial maturity, tertiary gas generation exhibited the opposite trend, with gas generation exhibiting lower activation energies of $310-320 \mathrm{~kJ} / \mathrm{mol}\left(A_{\mathrm{f}}=3.78-4.53 \times 10^{14}\right)$ than oil generation $(310-330 \mathrm{~kJ} / \mathrm{mol})$. This result suggests that gas compounds began to be the main product instead of oil compounds, as confirmed by the rising curve of gas yield and falling slope of oil yield in Fig. 6a, c. Thus, the generation of oil and gas were fully illustrated by the distribution of activation energy.

\subsection{Multiple hydrocarbon generation models for petroleum generation history}

It was assumed that hydrocarbon generation from coaly source rocks was predominantly affected by the burial history and thermal evolution, without considering differences in the abundance of organic matter and abnormal heating

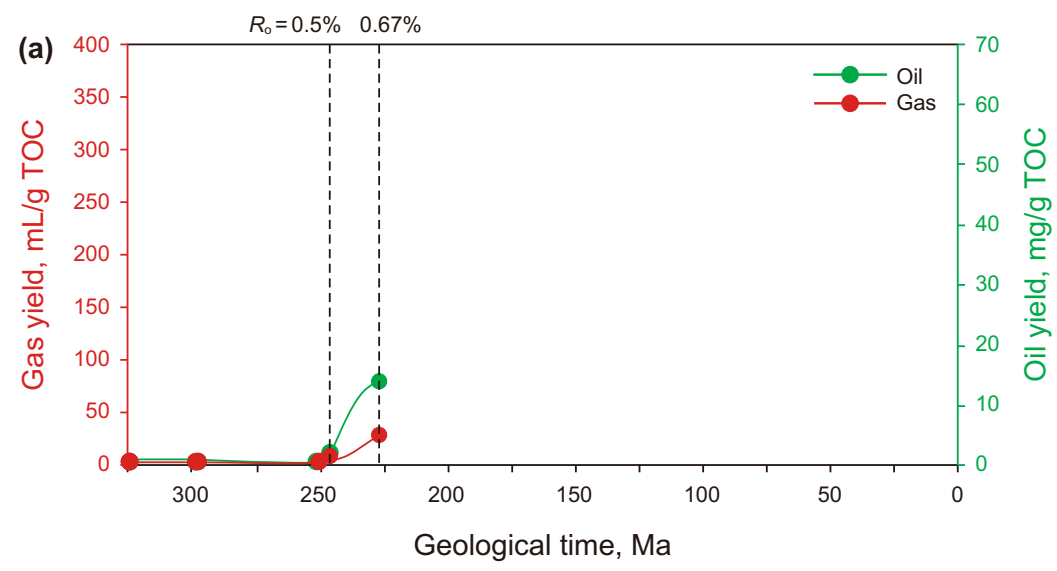

Fig. 7 Model of primary hydrocarbon generation

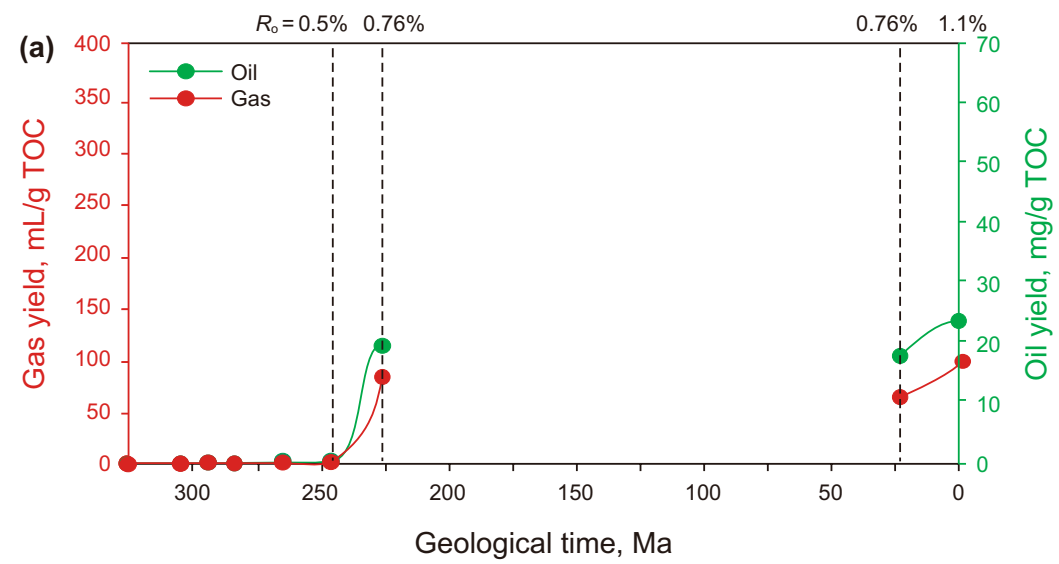

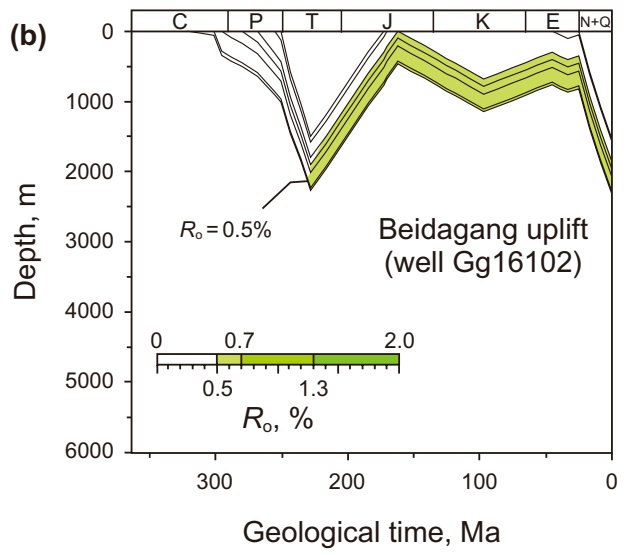

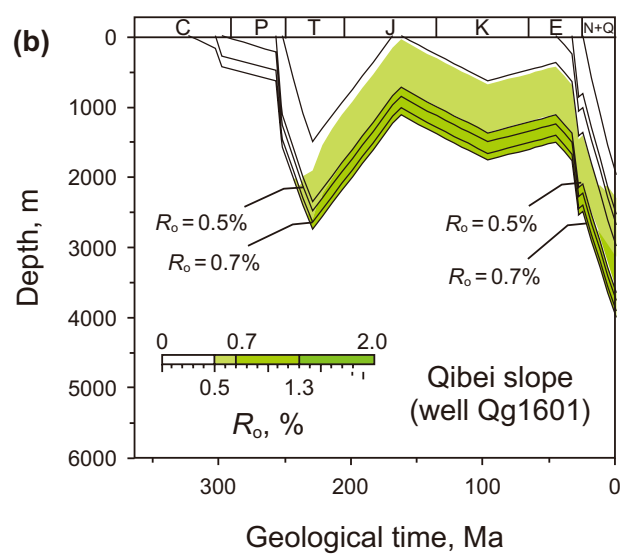

Fig. 8 Model of secondary hydrocarbon generation 
events (e.g., magmatic intrusion). By combining the thermal simulation experiment results and the thermal evolution history, three models of hydrocarbon generation were established to predict the oil and gas potential of coaly source rocks within different structural units.

\subsubsection{First generation event}

The first generation event only generated petroleum from the late $\mathrm{P}$ to early $\mathrm{T}$. The quantity of generated oil and gas was dominated by the thermal evolution degree and oil was the main product (Figs. 7b, 8b). Buried between $2000 \mathrm{~m}$ and $2600 \mathrm{~m}$, the source rocks underwent minimal maturation, varying from $0.5 \%$ to $0.7 \% R_{\mathrm{o}}$ in the Beidagang uplift area and reaching $0.7 \%-0.8 \% R_{\mathrm{o}}$ in the Qibei slope area. Hydrocarbon generation began at $250 \mathrm{Ma}$ and ceased at $225 \mathrm{Ma}$ (Fig. 7). Taking well Gg16102 as an example, the source rock ended with $R_{\mathrm{o}}$ values of $0.67 \%$, and the oil yield was $14.99 \mathrm{mg} / \mathrm{g}$ TOC. A minor amount of gas was generated, approximately $31.28 \mathrm{~mL} / \mathrm{g}$ TOC (Fig. 7a).

\subsubsection{Second generation event}

The second generation event includes early- and late-secondary hydrocarbon generation, characterized by the decomposition of kerogen from the Paleogene to the present day, which may have accumulated in petroleum reservoirs. Due to deeper burial, primary hydrocarbon generation of well Qg1601 ended at a mature stage with $R_{\mathrm{o}}$ values of $0.76 \%$ (Fig. 8). Compared to the low initial maturity of the first generation event, the oil and gas yields increased to $19.48 \mathrm{mg} / \mathrm{g}$ TOC and $95.93 \mathrm{~mL} / \mathrm{g}$ TOC, respectively, in the second generation event (Fig. 8a). Secondary hydrocarbon generation occurred during the Neogene from $98 \mathrm{Ma}$ to present and remained in a mature stage with $R_{\mathrm{o}}$ values of $0.76 \%-1.1 \%$ (Fig. 8b). Higher oil and gas yields were calculated, from
15.77-24.83 mg/g TOC and 77.08-101.71 mL/g TOC, respectively (Fig. 8a).

\subsubsection{Third generation event}

Under the influence of Indosinian, Yanshan, and Himalayan tectonic movement, C-P coals were buried to great depths, resulting in a third generation event during the late $\mathrm{T}$ and early to middle $\mathrm{K}$ and $\mathrm{E}$. The onset and duration of the secondary and tertiary hydrocarbon generation events differed depending on their location, leading to variations in the petroleum yield. In the regional depression of Huabei craton, primary hydrocarbon generation in the Permian was similar to that of the first generation event model. Early-secondary hydrocarbon generation occurred during the Mesozoic from 175 to $98 \mathrm{Ma}$ (Fig. 9b) with oil yields ranging from 13.87 to $28.83 \mathrm{mg} / \mathrm{g}$ TOC $\left(0.67 \%-0.90 \% R_{\mathrm{o}}\right.$; Fig. $\left.9 \mathrm{a}\right)$. However, the gas yield only increased from 30.59 to $77.09 \mathrm{~mL} / \mathrm{g}$ TOC. The last generation event lasted from 24.6 Ma to present and generated large amounts of condensate and natural gas (Fig. 9b). The tertiary hydrocarbon generation event was characterized by lower oil yields and higher gas yields. With increasing $R_{\mathrm{o}}$ values, the oil yield decreased substantially from that of primary and secondary hydrocarbon generation, from $8.25 \mathrm{mg} / \mathrm{g}$ TOC to $16.42 \mathrm{mg} / \mathrm{g}$ TOC. In contrast, gas was generated more rapidly and at a higher level, with current yields of $165.12 \mathrm{~mL} / \mathrm{g}$ TOC, which is favorable for the formation of petroleum pools (Fig. 9a).

\subsection{Factors controlling multiple hydrocarbon generation events}

Multi-stage tectonic movements and variable geothermal gradients from the Paleozoic to the Cenozoic may be responsible for the multiple hydrocarbon generation events of coaly source rocks. Regional subsidence occurred during
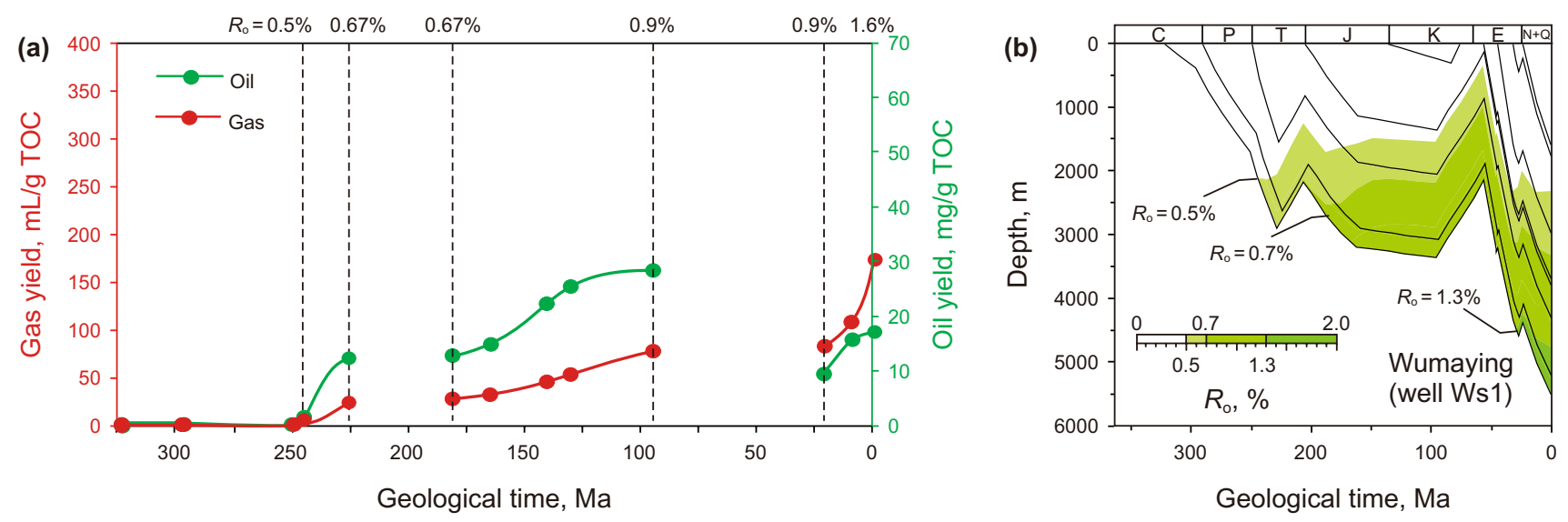

Fig. 9 Model of tertiary hydrocarbon generation 
the late $\mathrm{P}$ to early $\mathrm{T}$, and the geothermal gradient reached $3.5{ }^{\circ} \mathrm{C} / 100 \mathrm{~m}$. Whole source rocks experienced primary hydrocarbon generation, with $R_{\mathrm{o}}$ values ranging from $0.5 \%$ to $0.7 \%$ (Zhang et al. 2014; Chang et al. 2018). Subsequently, regionally integrated rapid uplift occurred within the Huabei platform. Diverse tectonic activity began in the late $\mathrm{T}$, which controlled various trends of the hydrocarbon generation events. Furthermore, due to strong magmatic activity with local magmatic intrusions, the geothermal gradient increased to approximately $5.0{ }^{\circ} \mathrm{C} / 100 \mathrm{~m}$ in the Mesozoic (Zhang et al. 2014). Deeply buried areas exhibited highly mature early-secondary hydrocarbon generation, with a higher heating rate than that of primary hydrocarbon generation. However, the uplifted and eroded area ceased to generate petroleum. During the Cenozoic, the different generation processes were enhanced in a complex manner, with geothermal gradients decreasing again to $3.5^{\circ} \mathrm{C} / 100 \mathrm{~m}$ (Li et al. 2007a, b). The current burial depth favors hydrocarbon generation and is also significant for forming petroleum pools. In some areas, the coaly source rocks only exhibited a primary hydrocarbon generation event as they have remained buried at shallow depths since the late J. Some source rocks were once again buried to form petroleum during the latesecondary hydrocarbon generation event from the Paleogene after uplift during the Mesozoic. The crucial tertiary hydrocarbon generation event also occurred in the Paleogene after primary and early-secondary hydrocarbon generation events during the Paleozoic and Mesozoic, respectively (Jin et al. 2009; Zhang et al. 2009; Cheng et al. 2018). Thus, tectonic evolution and geothermal gradients were key factors controlling the multiple hydrocarbon generation events.

Compared to continuous hydrocarbon generation, the total hydrocarbon generated during the three events exhibited a decreasing trend. Due to hydrocarbon generation ceasing multiple times, the hydrocarbon generation peak and yield was delayed and reduced with increasing activation energy. Although petroleum yields varied from primary to tertiary hydrocarbon generation events according to the initial and final maturity values, the initial maturity value had a dominant effect on the petroleum generation potential of coaly source rocks. With increasing initial maturity throughout the different generation events, the oil generation peak was delayed and reduced (Fig. 6). A greater difference in the initial maturities of different generation events would result in higher hysteresis.

\subsection{Effective hydrocarbon generation forming petroleum pools}

Analysis of the different generation models suggests that late-secondary hydrocarbon generation and tertiary hydrocarbon generation were the most useful for forming oil-gas pools. The scale of the paleo-reservoir was likely controlled by the initial maturity of tertiary hydrocarbon generation, with low initial maturity resulting in adequate oil and gas generation. Observations of condensate oil and gas in well Yg1 from C-P coaly source rocks confirm the hypothesis of reservoir formation from tertiary hydrocarbon generation (Zhao et al. 2018). The low initial maturity of late-secondary hydrocarbon generation suggests considerable condensate oil and gas potential from coaly source rocks.

In order to accurately predict the petroleum resource potential of coaly source rocks, the hydrocarbon generation parameters of oil and gas yields are required (Jin et al. 2009; Zhang et al. 2009; Cheng et al. 2018), which were obtained in this study. The oil and gas quantities generated from different periods of the generation events are critical functions for evaluating the petroleum resource potential of coaly source rocks, which is the aim of this study (Boreham et al. 1999; McCarthy et al. 2011). This study indicates the resource potential of coaly source rocks within late-secondary and tertiary hydrocarbon generation events during the Neogene, and reveals the Bohai Bay Basin as an important field for deep exploration. Based on the thermal history, the Qibei slope, Qinan sag, Kongxi slope, and Wangguantun sag are all favorable areas for late-secondary hydrocarbon generation (Fig. 10). The Wumaying buried hill and Xingang area are favorable for tertiary hydrocarbon generation (Fig. 10). As a result of the multiple events of hydrocarbon generation, the mid-north area of Dagang oil field has crude oil and natural gas potential, whereas the mid-southern and northern areas of Dagang oil field are prone to generate more condensate and abundant natural gas (Fig. 10). Therefore, these areas, which are currently buried at depth, have significant potential resources of petroleum and natural gas.

Additionally, this study provides insights into hydrocarbon generation of coaly source rocks deposited in other depressions of the Bohai Bay Basin. Compared to the Huanghua Depression, the coaly source rocks deposited in the Jiyang and Linqing depressions experienced the same three hydrocarbon generation events; thus, they are also prone to generating abundant coaly-derived gas (Jin et al. 2009; Zhang et al. 2009; Huang et al. 2010; Lv et al. 2011). The coaly source rocks in the Jizhong depression and Dongpu sag experienced similar hydrocarbon generation events to the Qikou sag in the Huanghua Depression (Zheng et al. 2007; Zhao et al. 2018). Moreover, deeper burial depths are typically associated with significant coaly-derived gas potential (Li et al. 2007a, b; Lv et al. 2011; Gong et al. 2018). Therefore, the models established in this study can provide useful information for the exploration of C-P coaly source rocks in the Bohai Bay Basin. 


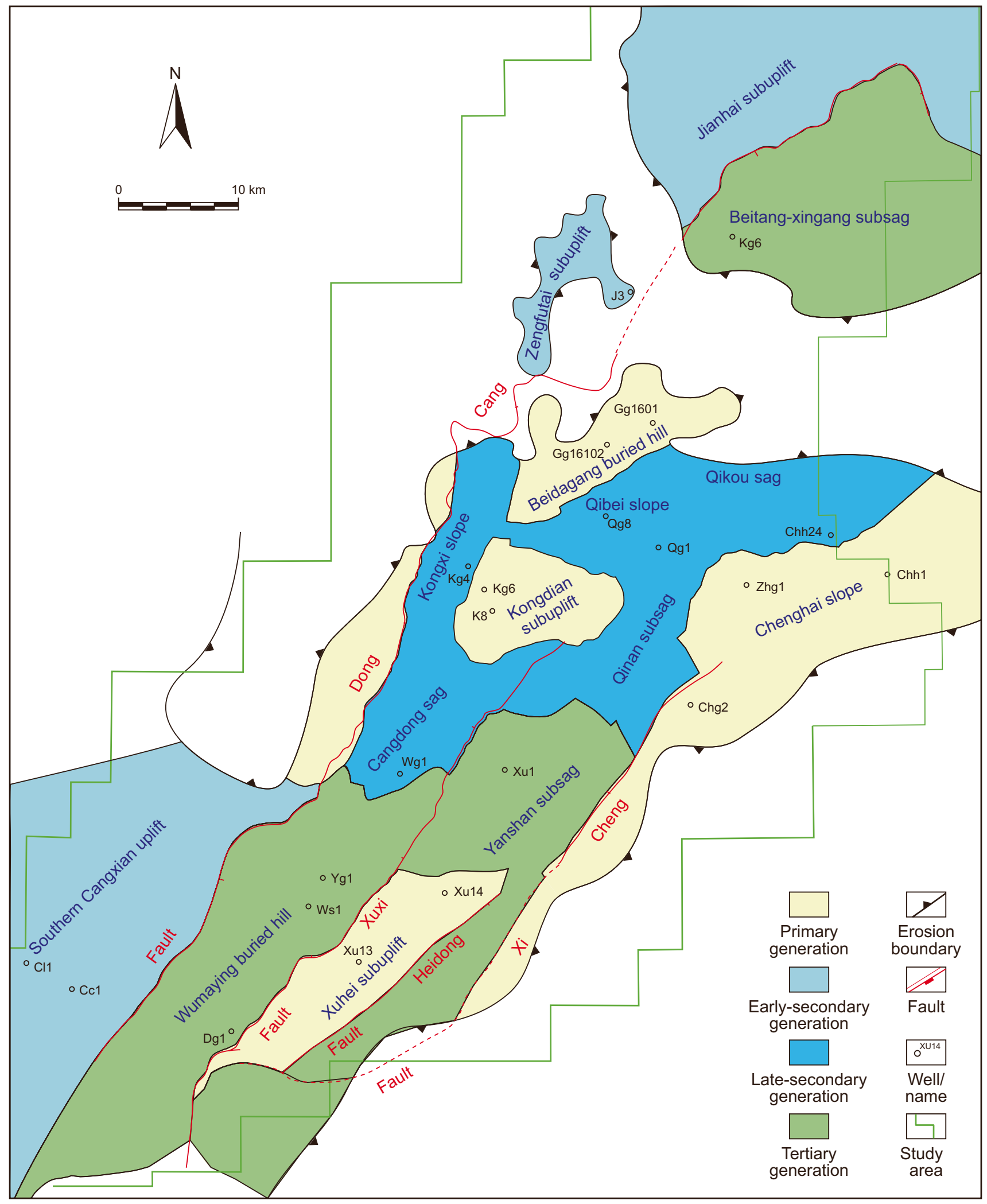

Fig. 10 Distribution of favorable areas under different hydrocarbon generation models 


\section{Conclusions}

Through organic geochemical analysis, geological process reconstruction, and thermal simulation experiments, the following conclusions were drawn in relation to the multiple hydrocarbon generation events of coaly source rocks in the Huanghua Depression:

1. Tectonic evolution and changes in geothermal gradient resulted in multiple hydrocarbon generation events of coaly source rocks in the Huanghua Depression, specifically primary, secondary, and tertiary hydrocarbon generation during the late $\mathrm{P}$ to early-middle $\mathrm{T}$, late $\mathrm{J}$ to early $\mathrm{K}$, and $\mathrm{E}$ to present day, respectively. The initial maturity of coaly source rocks increased throughout the hydrocarbon generation events, which affected the corresponding oil and gas yields.

2. The thermal simulation experiments and activation energy distribution indicated that the initial oil and gas yield of each generation event was lower than the final yields of the previous generation event. This trend became clearer with increasing initial maturity. The quantity and peak of oil and gas generation decreased from primary to secondary then tertiary hydrocarbon generation events, and was accompanied by an increase in activation energy. Tertiary hydrocarbon generation required higher depths and temperatures to activate petroleum regeneration.

3. Three generation models were established to represent the hydrocarbon generation events of the C-P coaly source rocks, including the timing, thermal evolution degree, and oil-gas yield of each event. Late-secondary and tertiary hydrocarbon generation events were most favorable for the formation of coaly-derived petroleum pools.

Acknowledgements The work presented in this paper was supported by the Certificate of National Science and Technology Major Project of the Ministry of Science and Technology of China (2016ZX05006007-004, 2016ZX05014), National Natural Science Foundation of China (41702139, U1663204, 41602138, 41602142), Natural Science Foundation of Shandong Province (ZR2017BD036, ZR2017LD005) and Fundamental Research Funds for the Central Universities (18CX02008A). We are grateful to the Geoscience Institute of the Dagang Oilfield, PetroChina, for permission to access their in-house database.

Open Access This article is licensed under a Creative Commons Attribution 4.0 International License, which permits use, sharing, adaptation, distribution and reproduction in any medium or format, as long as you give appropriate credit to the original author(s) and the source, provide a link to the Creative Commons licence, and indicate if changes were made. The images or other third party material in this article are included in the article's Creative Commons licence, unless indicated otherwise in a credit line to the material. If material is not included in the article's Creative Commons licence and your intended use is not permitted by statutory regulation or exceeds the permitted use, you will need to obtain permission directly from the copyright holder. To view a copy of this licence, visit http://creativecommons.org/licenses/by/4.0/.

\section{References}

Ahmed M, Volk H, George SC, Faiz M, Stalker L. Generation and expulsion of oils from Permian coals of the Sydney Basin. Australia. Org Geochem. 2009;40:810-31. https://doi.org/10.1016/j. orggeochem.2009.04.003.

Allen MB, Macdonald DI, Xun Z, Vincent SJ, Brouet-Menzies C. Transtensional deformation in the evolution of the Bohai Basin, northern China. Geol Soc Lond Spec Publ. 1998;135(1):215-29. https://doi.org/10.1144/GSL.SP.1998.135.01.14.

Belaid A, Krooss BM, Littke R. Thermal history and source rock characterization of a Paleozoic section in the Awbari Trough, Murzuq Basin, SW Libya. Mar Pet Geol. 2010;27(3):612-32. https://doi. org/10.1016/j.marpetgeo.2009.06.006.

Boreham CJ, Horsfield B, Schenk HJ. Predicting the quantities of oil and gas generated from Australian Permian coals, Bowen Basin using pyrolytic methods. Mar Pet Geol. 1999;16(2):165-88. https ://doi.org/10.1016/S0264-8172(98)00065-8.

Chang J, Qiu NS, Zhao XZ, Shen FY, Liu N, Xu W. Mesozoic and Cenozoic tectono-thermal reconstruction of the western Bohai Bay Basin (East China) with implications for hydrocarbon generation and migration. J Asian Earth Sci. 2018;160:380-95. https:// doi.org/10.1016/j.jseaes.2017.09.008.

Chang J, Qiu NS, Zhao XZ, Wei XU, Qiu-Chen XU, Jin FM e al. Present-day geothermal regime of the Jizhong depression in Bohai Bay basin, East China. Chin J Geophys-CH. 2016;59(3):1003-16. https://doi.org/10.6038/cjg20160322 (in Chinese).

Chen YY, Mastalerz M, Schimmelmann A. Characterization of chemical functional groups in macerals across different coal ranks via micro-FTIR spectroscopy. Int J Coal Geol. 2012;104:22-33. https ://doi.org/10.1016/j.coal.2012.09.001.

Cheng B, Chen ZH, Chen T, Yang CY, Wang TG. Biomarker signatures of the Ediacaran-Early Cambrian origin petroleum from the central Sichuan Basin, South China: implications for source rock characteristics. Mar Pet Geol. 2018;96:577-90. https://doi. org/10.1016/j.marpetgeo.2018.05.012.

Dai CL, Liang QM, Liu TT, Li JN, Zhang L, Wang S. Trace gas collector for oil and gas geochemical exploration. 2013 (in Chinese).

Dai JX, Xia YH. Ordovician gas accumulations in eastern China. J Pet Geol. 1990;13(1):79-86. https://doi. org/10.1111/j.1747-5457.1990.tb00253.x.

Dieckmann V. Modelling petroleum formation from heterogeneous source rocks: the influence of frequency factors on activation energy distribution and geological prediction. Mar Pet Geol. 2005;22(3):375-90. https://doi.org/10.1016/j.marpe tgeo.2004.11.002.

Gong DY, Li JZ, Ablimit I, He WJ, Lu S, Liu DG et al. Geochemical characteristics of natural gases related to Late Paleozoic coal measures in China. Mar Pet Geol. 2018;96:474-500. https://doi. org/10.1016/j.marpetgeo.2018.06.017.

Hao F, Zou HY, Gong ZS, Deng YH. Petroleum migration and accumulation in the Bozhong sub-basin, Bohai Bay Basin, China: significance of preferential petroleum migration pathways (PPMP) for the formation of large oilfields in lacustrine fault basins. Mar Pet Geol. 2007;24:1-13. https://doi.org/10.1016/j.marpe tgeo.2006.10.007. 
He JH, Ding WL, Zhang JC, Li A, Zhao W, Dai P. Logging identification and characteristic analysis of marine-continental transitional organic-rich shale in the Carboniferous-Permian strata, Bohai Bay Basin. Mar Pet Geol. 2016;70:273-93. https://doi.org/10.1016/j. marpetgeo.2015.12.006.

He K, Zhang SC, Mi JK, Zhang WL. The evolution of chemical groups and isotopic fractionation at different maturation stages during lignite pyrolysis. Fuel. 2018a;211:492-506. https://doi. org/10.1016/j.fuel.2017.09.085.

He QX, Ye YZ, Zhang MS, Li H. Transgression model of restricted epicontinental sea. Acta Sediment Sin. 1991;9(1):1-10 (in chinese).

He L, Hui HL, Li S, Lin WG. Production of light aromatic hydrocarbons by catalytic cracking of coal pyrolysis vapors over natural iron ores. Fuel. 2018b;216:227-32. https://doi.org/10.1016/j. fuel.2017.12.005

Huang SP, Liao FR, Wu XQ. Geochemical characteristics of Carboniferous-Permian coal-formed gas in Bohai Bay Basin. Energy Explor Exploit. 2010;28(1):13-24. https://doi. org/10.1260/0144-5987.28.1.13.

Jin Q, Song GQ, Wang L. Generation models of CarboniferousPermian coal-derived gas in Shengli oilfield. Pet Explor Dev. 2009;36(3):358-64 (in Chinese).

Kim JH, Yong IL, Li M, Bai Z. Comparison of the Ordovician-Carboniferous boundary between Korea and NE China: implications for correlation and tectonic evolution. Gondwana Res. 2001;4(1):3953. https://doi.org/10.1016/S1342-937X(05)70653-5.

Li L, Zhao L, Liu HJ, Fang XY, Geosciences SO. Late Mesozoic to Cenozoic extension and strike slip structures and deep background of Bohai Bay Basin. Sci Geol Sin. 2015;50:446-72. https://doi. org/10.3969/j.issn.0563-5020.2015.02.007 (in Chinese).

Li L, Ren ZL, Cui YB, Zhang S. Distribution of Present-day geothermal field in the dongpu sag. Sci Geol Sin. 2007a;42(4):787-94. https://doi.org/10.1016/s1872-5791(07)60044-x (in Chinese).

Li SZ, Zhao GC, Dai LM, Zhou LH, Liu X, Suo YH et al. Cenozoic faulting of the Bohai Bay Basin and its bearing on the destruction of the eastern North China Craton. J Asian Earth Sci. 2012;47:80 93. https://doi.org/10.1016/j.jseaes.2011.06.011.

Li ZS, Fredericks PM, Rintoul L, Ward CR. Application of attenuated total reflectance micro-Fourier transform infrared (ATR-FTIR) spectroscopy to the study of coal macerals: examples from the Bowen Basin, Australia. Int J Coal Geol. 2007b;70:87-94. https ://doi.org/10.1016/j.coal.2006.01.006.

Li ZX, Sun YZ, Yu JF, Liu DY. Marine transgression "Event" in coal formation from North China Basin. Energy Explor Exploit. 2001;19:559-67. https://doi.org/10.1260/0144598011492679 (in Chinese).

Liang C, Wu J, Jiang ZX, Cao YC, Song GQ. Sedimentary environmental controls on petrology and organic matter accumulation in the upper fourth member of the Shahejie Formation (Paleogene, Dongying depression, Bohai Bay Basin, China). Int J Coal Geol. 2018;186:1-13. https://doi.org/10.1016/j.coal.2017.11.016.

Liu GH. Permo-Carboniferous paleogeography and coal accumulation and their tectonic control in the North and South China continental plates. Int J Coal Geol. 1990;16:73-117. https://doi. org/10.1016/0166-5162(90)90014-P.

Liu QX, Song Y, Jiang L, Cao T, Chen ZH, Xiao DQ et al. Geochemistry and correlation of oils and source rocks in Banqiao Sag, Huanghua Depression, northern China. Int J Coal Geol. 2017;176:4968. https://doi.org/10.1016/j.coal.2017.04.005.

Lv DW, Chen JT. Depositional environments and sequence stratigraphy of the Late Carboniferous-Early Permian coal-bearing successions (Shandong Province, China): sequence development in an epicontinental basin. J Asian Earth Sci. 2014;79:16-30. https://doi. org/10.1016/j.jseaes.2013.09.003.

Lv DW, Li ZX, Chen JT, Liu HY, Guo JB, Shang LN. Characteristics of the Permian coal-formed gas sandstone reservoirs in Bohai
Bay Basin and the adjacent areas, North China. J Pet Sci Eng. 2011;78(2):516-28. https://doi.org/10.1016/j.petrol.2011.06.018.

McCarthy K, Rojas K, Niemann M, Palmowski D, Peters K, Stankiewicz A. Basic petroleum geochemistry for source rock evaluation. Oil Rev. 2011;23(2):32-43.

Pepper AS, Corvi PJ. Simple kinetic models of petroleum formation. Part I: Oil and gas generation from kerogen. Mar Pet Geol. 1995;12(3):291-319. https://doi.org/10.1016/02648172(95)98381-e.

Petersen HI, Lindström S, Nytoft HP, Rosenberg P. Composition, peatforming vegetation and kerogen paraffinicity of Cenozoic coals: relationship to variations in the petroleum generation potential (Hydrogen Index). Int J Coal Geol. 2009;78(2):119-34. https:// doi.org/10.1016/j.coal.2008.11.003.

Petersen HI, Nytoft HP. Oil generation capacity of coals as a function of coal age and aliphatic structure. Org Geochem. 2006;37(5):55883. https://doi.org/10.1016/j.orggeochem.2005.12.012.

Qi JF, Yang Q. Cenozoic structural deformation and dynamic processes of the Bohai Bay basin province, China. Mar Pet Geol. 2010;27(4):757-71. https://doi.org/10.1016/j.marpe tgeo.2009.08.012.

Schenk O, Peters K, Burnham A. Evaluation of alternatives to Easy\% $R_{\mathrm{o}}$ for calibration of basin and petroleum system models. In: 79th EAGE conference and exhibition 2017.

Su JB, Zhu WB, Chen J, Min B, Zheng B. Wide rift model in Bohai Bay Basin: insight into the destruction of the North China Craton. Int Geol Rev. 2014;56:537-54. https://doi.org/10.1080/00206 814.2013.879373.

Tian KQ, Shi YM, Qin RZ, McMillan NJ, Lee PJ. Petroleum geology of the Huanghua Basin, eastern China. Bull Can Petrol Geol. 1996;44(4):595-614. https://doi.org/10.35767/gscpg bull.44.4.595.

Wang M, Li Z, Huang W, Yang J, Xue H. Coal pyrolysis characteristics by TG-MS and its late gas generation potential. Fuel. 2015;156:243-53. https://doi.org/10.1016/j.fuel.2015.04.055.

Walker R, Mastalerz M, Brassell S, Elswick E, Hower JC, Schimmelmann A. Chemistry of thermally altered high volatile bituminous coals from southern Indiana. Int J Coal Geol. 2007;71(1):2-14. https://doi.org/10.1016/j.coal.2006.06.009.

$\mathrm{Yu}$ XL, Bai F, Li ZM. Application of attenuated total reflectancemicro-Fourier transform infrared (ATR-FTIR) spectroscopy to in situ study of coal macerals. Pet Geol Exp. 2012;34(6):664-70. https://doi.org/10.11781/sysydz201206664 (in Chinese).

Zhang SW, Zhang LY, Li Z. Analysis of accumulation process of coal-formed gas in Gubei buried hill of Jiyang depression. Nat Gas Geosci. 2009;20:670-7. https://doi.org/10.11764/j.i ssn.1672-1926.2009.05.670 (in Chinese).

Zhang SH, Tang SH, Qian Z, Pan ZJ, Guo QL. Evaluation of geological features for deep coalbed methane reservoirs in the Dacheng Salient, Jizhong Depression, China. Int J Coal Geol. 2014;133:60-71. https://doi.org/10.1016/j.coal.2014.09.002.

Zhao JH, Jin ZK, Jin ZJ, Wen X, Geng YK. Origin of authigenic quartz in organic-rich shales of the Wufeng and Longmaxi Formations in the Sichuan Basin, South China: implications for pore evolution. J Nat Gas Sci Eng. 2017;38:21-38. https://doi.org/10.1016/j.jngse .2016.11.037.

Zhao XZ, Jin FM, Wang Q, Bai GP. Buried-hill play, Jizhong subbasin, Bohai Bay Basin: a review and future prospectivity. AAPG Bull. 2015;99:1-26. https://doi.org/10.1306/07171413176.

Zhao XZ, Zhou LH, Pu XG, Jiang WY, Jin FM, Xiao DQ et al. Hydrocarbon-generating potential of the Upper Paleozoic section of the Huanghua Depression, Bohai Bay Basin, China. Energy Fuel. 2018;32(12):12351-64. https://doi.org/10.1021/acs.energyfuel s.8b03159.

Zheng LQ, Li X, Lu XQ, Zhong NN, Huang XY, Zhou Q. Thermal evolution of organic matter and secondary hydrocarbon generation 
from upper Paleozoic coal deposits in northern China. J China Univ Min Technol. 2007;17(4):526-33 (in Chinese).

Zhou LH, Fu LX, Lou D, Lu Y, Feng JY, Zhou SH et al. Structural anatomy and dynamics of evolution of the Qikou Sag, Bohai Bay
Basin: implications for the destruction of North China craton. J Asian Earth Sci. 2012;47:94-106. https://doi.org/10.1016/j.jseae s.2011.06.004. 